\title{
Calciphylaxis in a patient affected by rheumatoid arthritis, chronic renal failure, and hyperparathyroidism: a case report
}

This article was published in the following Dove Press journal:

International Medical Case Reports Journal

27 May 2015

Number of times this article has been viewed

\author{
Alfredomaria Lurati' \\ Antonella Laria' \\ Donatella Paolotti² \\ Magda Scarpellini' \\ 'Rheumatology Unit, ${ }^{2}$ Department \\ of Pathology, Fornaroli Hospital \\ Magenta, Magenta, Italy
}

\begin{abstract}
Calciphylaxis, or calcific uremic arteriolopathy, is the tissue and vascular calcification that occurs mainly in chronic kidney disease. However, it can be secondary to parathyroid dysfunction and it has been described in rheumatic patients. We present a case of calciphylaxis in a woman with inactive rheumatoid arthritis, acute renal failure, and hyperparathyroidism.

Keywords: calciphylaxis, rheumatoid arthritis, renal failure, hyperparathyroidism
\end{abstract}

\section{Introduction}

Calciphylaxis, or calcific uremic arteriolopathy (CUA), described for the first time by Selye, ${ }^{1}$ is increased tissue sensitivity to calcification affecting the small and medium vessels (especially in the skin); it leads to ischemia and then to cutaneous necrosis. ${ }^{2}$ It primarily affects $1 \%-4 \%$ of patients with renal failure, but it can also be secondary to parathyroid dysfunction and, less frequently, it has been reported in patients with lymphoma, leukemia, and multiple myeloma. ${ }^{3-5}$ There are only a few cases that have been described in patients with rheumatic diseases, such as in rheumatoid arthritis (RA) without renal insufficiency and hyperparathyroidism, as well as in patients affected by systemic lupus erythematosus, giant cell arteritis, or antiphospholipid antibody syndrome. ${ }^{5}$ As for other rheumatic diseases, the systemic inflammatory state due to RA often involves microcirculation and becomes a possible predisposing factor to calciphylaxis. ${ }^{6-8}$ We present a case of calciphylaxis in a woman with inactive RA, acute renal insufficiency, and hyperparathyroidism, as well as with long-term steroid therapy and immunosuppressive drugs.

\section{Case report}

In November 2014, an 80-year-old female affected by RA and who was seropositive for anticyclic citrullinated peptide antibodies and rheumatoid factor was admitted to the rheumatology division of our hospital for the appearance of acute renal failure and some painful skin lesions on her lower limbs while taking the diseasemodifying antirheumatic drug, leflunomide, and low doses of prednisone $(5 \mathrm{mg} / \mathrm{day}$ as long-term therapy). Other comorbidities included osteoarthritis, dorsal vertebral osteoporotic fractures, arterial hypertension during pharmacological treatment, and bowel diverticulosis. RA was diagnosed in August 2010 and therapy with methotrexate was started at a dose of $15 \mathrm{mg} /$ week with low doses of prednisone. Therapy with methotrexate yielded a good clinical response, but after some months it was stopped because of alopecia. We then decided to start treatment with leflunomide $20 \mathrm{mg} /$ day.
Correspondence: Alfredomaria Lurat Rheumatology Unit, Fornaroli Hospital Magenta, Via Donatore Sangue 50, Magenta, Italy $\mathrm{Tel}+390297963843$

Email alfredomaria.lurati@ao-legnano.it (c) (i) (2) 2015 Lurati et al. This work is published by Dove Medical Press Limited, and licensed under Creative Commons Attribution - Non Commercial (unported, v3.0) permission from Dove Medical Press Limited, provided the work is properly attributed. Permissions beyond the scope of the License are administered by Dove Medical Press Limited. Information on how to request permission may be found at: http://www.dovepress.com/permissions.php 
Laboratory tests performed in September 2014 showed a creatinine level of $0.6 \mathrm{mg} / \mathrm{dL}$ (normal range: $0.1-1.02 \mathrm{mg}$ / $\mathrm{dL}$ ), an erythrocyte sedimentation rate (ESR) of $55 \mathrm{~mm} /$ hour (cut-off value: $\leq 20 \mathrm{~mm} /$ hour), a C-reactive protein level of $3.17 \mathrm{mg} / \mathrm{dL}$ (normal range: $0-5 \mathrm{mg} / \mathrm{dL}$ ), serum total calcium levels of $8.72 \mathrm{mg} / \mathrm{dL}$ (normal range: $8.4-10.4 \mathrm{mg} / \mathrm{dL}$ ), a 25-hydroxy vitamin $\mathrm{D}$ level of $32.31 \mathrm{ng} / \mathrm{mL}$ (normal range: $\geq 30 \mathrm{ng} / \mathrm{mL}$ ), a phosphorus level of $4.6 \mathrm{mg} / \mathrm{dL}$ (normal range: $2.2-4.5 \mathrm{mg} / \mathrm{dL}$ ), and a parathyroid hormone (PTH) level of $394 \mathrm{pg} / \mathrm{mL}$ (normal range: $12-72 \mathrm{pg} / \mathrm{mL}$ ). Low urine total calcium, low urine total phosphorus, and low urine total magnesium levels were observed equal to $9.84 \mathrm{mg} / 24$ hours (normal range: 100-300 mg/24 hours), $189 \mathrm{mg} / 24$ hours (normal range: 400-1,300 mg/24 hours), and $26.4 \mathrm{mg} / 24$ hours (normal range: $73-122 \mathrm{mg} / 24$ hours), respectively.

During hospital admission, the patient reported only rachialgia associated with oliguria (diuresis $<500$ $\mathrm{mL} / 24$ hours). The patient presented with livedo reticularis and she had many painful, erythematous, necrotic skin lesions on her lower limbs (Figure 1). Laboratory tests showed the following: a creatinine level of $2.21 \mathrm{mg} / \mathrm{dL}$ (normal range: 0.1-1.02 mg/dL); a blood urea nitrogen level of $89.4 \mathrm{mg} / \mathrm{dL}$ (normal range: $20-45 \mathrm{mg} / \mathrm{dL}$ ); creatinine clearance of $41 \mathrm{~mL} /$ minute; an ESR of $11 \mathrm{~mm} /$ hour (cut-off value: $\leq 20 \mathrm{~mm} /$ hour); and a C-reactive protein level of $0.29 \mathrm{mg}$ / $\mathrm{dL}$ (normal range: $0-5 \mathrm{mg} / \mathrm{dL}$ ). The kalium potassium level was $2.63 \mathrm{mEq} / \mathrm{L}$ (normal range: $3.5-5.20 \mathrm{mEq} / \mathrm{L}$ ), the magnesium level was $1.22 \mathrm{mg} / \mathrm{dL}$ (normal range: 1.4-2.6 dL), and the serum calcium level was $7.7 \mathrm{mg} / \mathrm{dL}$ (normal range: 8.4-10.4 mg/dL). Serum sodium bicarbonate was normal (23 mEq/L with a normal range of $21-30 \mathrm{mEq} / \mathrm{L})$. The serum total phosphorus level was $4.76 \mathrm{mg} / \mathrm{dL}$ (normal range:

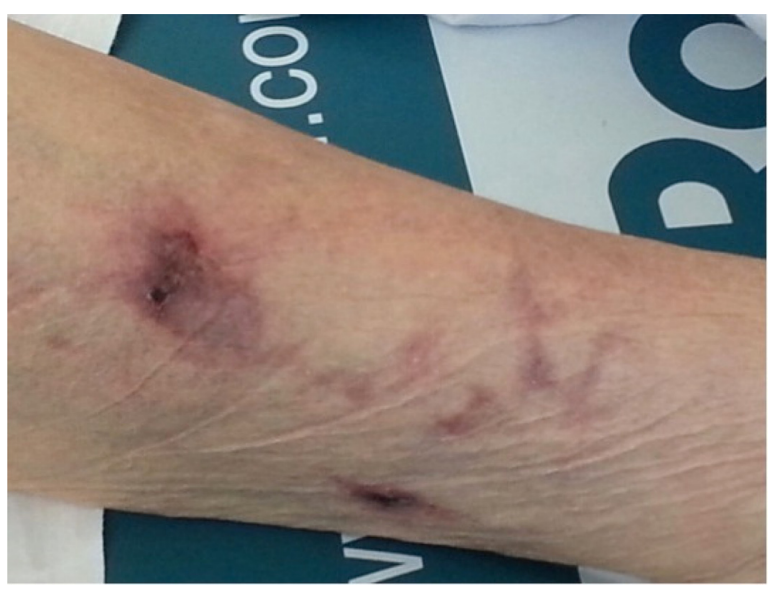

Figure I Skin lesions in calciphylaxis.

Note: Livedo reticularis and erythematous, necrotic, nonhealing skin lesions of the lower-right limb.
2.2-4.5 mg/dL), 25-hydroxy vitamin D was $21.35 \mathrm{ng} / \mathrm{mL}$ (normal range: $\geq 30 \mathrm{ng} / \mathrm{mL}$ ), and the PTH level was 531.4 $\mathrm{pg} / \mathrm{mL}$ (normal range: $12-72 \mathrm{pg} / \mathrm{mL}$ ). Doppler ultrasound of the lower limbs ruled out deep vein thrombosis. Renal echography did not show parenchymal involvement. Skeletal X-ray of the lower limbs showed diffuse vascular calcifications. A skin biopsy of the lesions showed calcific sclerosis and microthrombi within a small artery with calcium deposition. A final diagnosis of calciphylaxis was made (Figures 2-4). Daily antibiotic treatment of the local cutaneous lesions was performed. Bisphosphonate treatment with sodium clodronate was given at a dose of $300 \mathrm{mg} /$ day intravenously for 10 days, together with a low dose of colecalciferol $(2,500$ U/weekly) with tight control of calcium and phosphorus hematic levels. Slow but progressive improvement was also observed.

\section{Discussion}

Calciphylaxis can be regarded as a vasculopathy that affects the small and medium vessels. Skin lesions consist of nonhealing ulcers that are accompanied by livedo reticularis. Other forms of vasculitis have to be excluded. Skin ulcers evolve into skin necrosis with secondary infections, leading to sepsis. Other rare systemic manifestations are aortic valve involvement, pulmonary calciphylaxis, recurrent digital ischemia, gangrene, weakness, cardiomyopathy, and mesenteric ischemia. ${ }^{9}$ The pathogenesis of calciphylaxis is still unknown and it is probably multifactorial. In the majority of patients, it is secondary to a dysregulation of the calcium-phosphateparathyroid axis. ${ }^{10}$ It is well known that patients with an elevated calcium-phosphate product, particularly when the

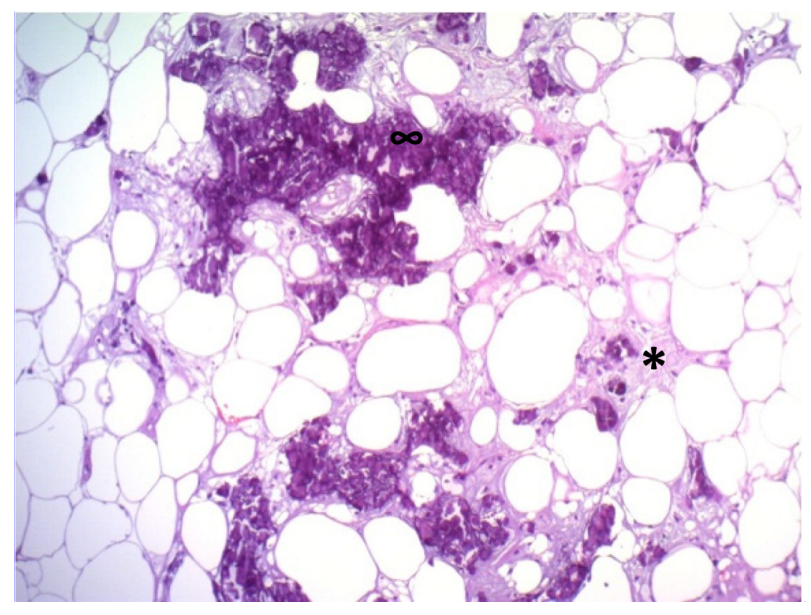

Figure 2 Hematoxylin and eosin stain, magnification I00X.

Note: Hematoxylic calcification of the tunica media of the small vessels $\left({ }^{*}\right)$ and interstitium $(\infty)$. 


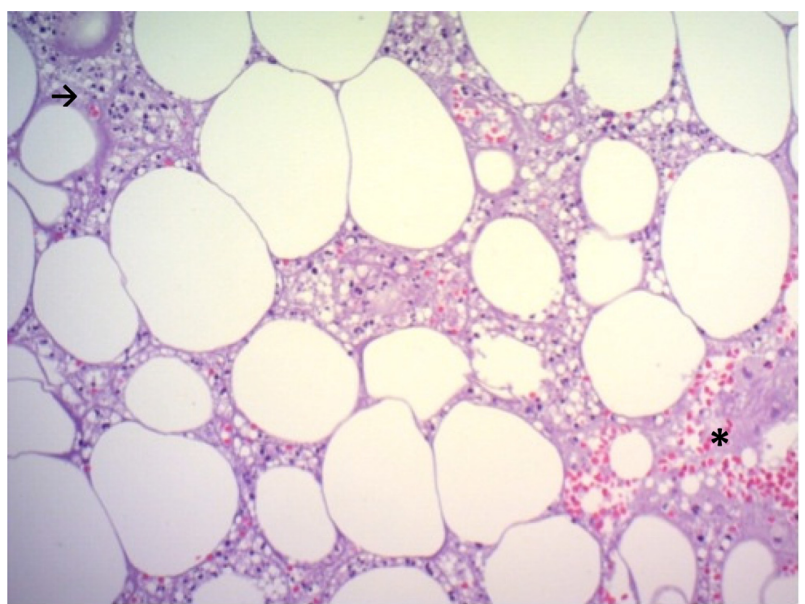

Figure 3 Hematoxylin and eosin stain, magnification 200x.

Note: Lipid hemorrhagic necrosis $(*)$ and lymphohistiocytic infiltrate (arrow).

level is $>60 \mathrm{mg}^{2} / \mathrm{dL}^{2}$, are at high risk of developing CUA. ${ }^{9}$ However, in a significant proportion of patients, calcium and phosphorus levels are normal. It has been suggested that in such patients, the calcification develops as a direct response to excess PTH or vitamin D. ${ }^{11}$

Many factors can alter the prognosis of calciphylaxis. Lo Monte et $\mathrm{al}^{12}$ described a case report of hemolytic uremic syndrome in a 60-year-old female patient who was also affected by secondary hyperparathyroidism in end-stage renal failure. This showed that the existence of these comorbidities makes the prognosis poor. Moreover, the authors also showed that in this case, therapy - which counteracts calcium crystal precipitation - has no effect. Preventive parathyroidectomy can

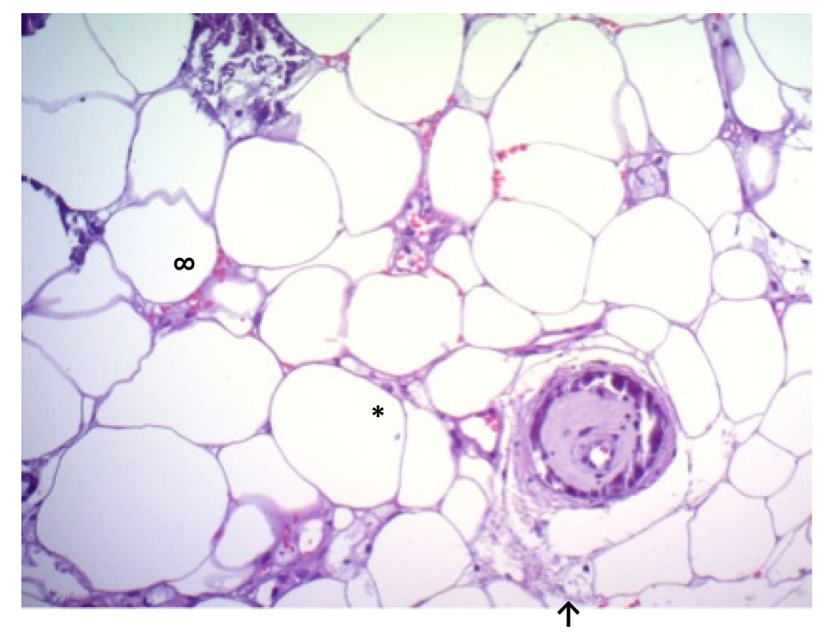

Figure 4 Hematoxylin and eosin stain, magnification 200x.

Notes: Schematic representation of calciphylaxis. On the lower-right side: $(\uparrow)$ transverse section of a small vessel with edema of the tunica media and the tunica intima without any lesions; $(*)$ perivascular and interstitial lymphohistiocytic infiltrate; and $(\infty)$ perivascular and interstitial calcifications on the upper-left side. All of these elements were surrounded by adipocytes with hemorrhagic lipid necrosis. be considered as the only possible treatment. ${ }^{12}$ The calcium deposits on small vessels during secondary hyperparathyroidism can induce a complex hypersensitivity reaction that could precipitate the pre-existing vascular alteration in hemolytic uremic syndrome-related thrombotic microangiopathy, explaining the ineffectiveness of sodium thiosulfate therapy. ${ }^{13}$ Extra-articular RA manifestations can include alterations in microcirculation, such as small-vessel vasculitis, which can induce calciphylaxis in the presence of other factors. Histologically, the characteristic feature is calcification of the small- to medium-sized arterioles and arterioles involving both the tunica media and tunica intima. Calcified debris may sometimes be present within the lumen and occasionally the vessels are thrombosed. Intimal fibroblastic proliferation with luminal narrowing has also been described. Hemorrhages within the subcutaneous fat may be seen, and fat necrosis accompanied by a lobular lymphohistiocytic infiltrate has been documented in a number of cases. ${ }^{12,13}$ Disease should be suspected clinically in those patients with altered calcium-phosphate product or elevated levels of PTH, and laboratory tests should be performed to exclude autoimmune disease or infections (including antineutrophil cytoplasmic antibody, hepatitis B and C serologies, complement levels, and cryoglobulin levels). Skin biopsy is the gold standard for diagnosis. ${ }^{9}$ Our patient presented only with skin involvement. In our case report, the pathogenesis of calciphylaxis was multifactorial (RA, chronic renal failure, and secondary/ tertiary hyperparathyroidism). The gold standard of treatment is supportive care with electrolytic corrections, hydration, and nutrition. ${ }^{13}$ It is very important that local care is provided and that antibiotic agents are used immediately after the infection is detected (considering that the mortality of CUA relates to the development of sepsis). Debridation of necrotic tissue is generally effective and improves the healing of skin ulcers. It is recommended that risk factors for CUA are eliminated, such as diabetes and obesity. As such, a diet without calciumphosphate is necessary so that the calcium-phosphate product can remain $<55 \mathrm{mg}^{2} / \mathrm{dL}^{2}$, and serum phosphorus can remain between $2.7 \mathrm{mg} / \mathrm{dL}$ and $4.6 \mathrm{mg} / \mathrm{dL}$.

It is useful to prescribe a phosphate binder, such as sevelamer and lanthanum carbonate, thus eliminating binders that contain calcium salts. ${ }^{14}$ Cinacalcet is a possible therapeutic option for CUA. It is a calcimimetic and it helps to downregulate PTH levels and normalize calcium and phosphorus metabolism. It is currently used mainly in patients with secondary hyperparathyroidism resulting from chronic renal insufficiency. In CUA, cinacalcet (starting at a dose of $30 \mathrm{mg}$ daily and eventually titrated to $60 \mathrm{mg}$ daily) has 
been reported in a few case reports to decrease pain, reduce PTH levels, correct significantly elevated calcium-phosphate product levels, and dramatically heal cutaneous ulcers. ${ }^{13,15}$ In several case reports, bisphosphonates, such as intravenous pamidronate, clodronate, and oral etidronate, have also shown a significant decrease in pain, and these agents have been implicated in the healing of cutaneous ulcers. ${ }^{14-19}$ Finally, hyperbaric oxygen is a possible treatment, as it increases the quantity of oxygen that arrives to the peripheral tissues, thus increasing the healing of skin ulcers.

\section{Disclosure}

The authors report no conflicts of interest in this work.

\section{References}

1. Selye H. Calciphylaxis. Chicago, Il: University of Chicago Press; 1962.

2. Ozbalkan Z, Calguneri M, Onat AM, Ozturk MA. Development of calciphylaxis after long-term steroid and methotrexate use in a patient with rheumatoid arthritis. Intern Med. 2005;44(11):1178-1181.

3. Angelis M, Wong LL, Myers SA, Wong LM. Calciphylaxis in patients on hemodialysis: a prevalence study. Surgery. 1997;122(6):1083-1090.

4. Parker RW, Mouton CP, Young DW, Espino DV. Early recognition and treatment of calciphylaxis. South Med J. 2003;96(1):53-55.

5. Oh DH, Eulau D, Tokugawa DA, McGuire JS, Kohler S. Five cases of calciphylaxis and a review of the literature. $J$ Am Acad Dermatol. 1999;40(6 Pt 1):979-987.

6. Korkmaz C, Dündar E, Zubaroğlu I. Calciphylaxis in a patient with rheumatoid arthritis without renal failure and hyperparathyroidism: the possible role of long-term steroid use and protein S deficiency. Clin Rheumatol. 2002;21(1):66-69.

7. Sakr SH, Russell EB, Jasin HE. Systemic lupus erythematosus and calciphylaxis. J Rheumatol. 2004;31(9):1851-1853.
8. Gertner E. Calciphylaxis: a not-so-rare pseudovasculitis syndrome. J Clin Rheumatol. 1999;5(4):210-214.

9. Lee JL, Naguwa SM, Cheema G, Gershwin ME. Recognizing calcific uremic arteriolopathy in autoimmune disease: an emerging mimicker of vasculitis. Autoimmun Rev. 2008;7(8):638-643.

10. Gipstein RM, Coburn JW, Adams DA, et al. Calciphylaxis in man. A syndrome of tissue necrosis and vascular calcification in 11 patients with chronic renal failure. Arch Intern Med. 1976;136(11):1273-1280.

11. Selye H, Gabbiani G, Strebel R. Sensitization to calciphylaxis by endogenous parathyroid hormone. Endocrinology. 1962;71:554-558.

12. Lo Monte AI, Bellavia M, Damiano G, et al. A complex case of fatal calciphylaxis in a female patient with hyperparathyroidism secondary to end stage renal disease of graft and coexistence of haemolytic uremic syndrome. Biomed Pap Med Fac Univ Palacky Olomouc Czech Repub. 2012;156(3):262-265.

13. Lo Monte AI, Bellavia M, Maione C, et al. Systemic calciphylaxis and thrombotic microangiopathy in a kidney transplant patient: two mixing fatal syndromes? Med Hypotheses. 2012;79(1):74-75.

14. Kidney Disease: Improving Global Outcomes (KDIGO) CKD-MBD Work Group. KDIGO clinical practice guidelines for the diagnosis, evaluation, prevention, and treatment of chronic kidney disease-mineral and bone disorder (CKD-MBD). Kidney Int Suppl. 2009;(113):S1-S130.

15. Monney P, Nguyen QV, Perroud H, Descombes E. Rapid improvement of calciphylaxis after intravenous pamidronate therapy in a patient with chronic renal failure. Nephrol Dial Transplant. 2004;19(8): 2130-2132.

16. Robinson MR, Augustine JJ, Korman NJ. Cinacalcet for the treatment of calciphylaxis. Arch Dermatol. 2007;143(2):152-154.

17. Velasco N, MacGregor MS, Innes A, MacKay IG. Successful treatment of calciphylaxis with cinacalcet-an alternative to parathyroidectomy? Nephrol Dial Transplant. 2006;21(7):1999-2004.

18. Hanafusa T, Yamaguchi Y, Tani M, Umegaki N, Nishimura Y, Katayama I. Intractable wounds caused by calcific uremic arteriolopathy treated with bisphosphonates. J Am Acad Dermatol. 2007;57(6):1021-1025.

19. Shiraishi N, Kitamura K, Miyoshi T, et al. Successful treatment of a patient with severe calcific uremic arteriolopathy (calciphylaxis) by etidronate disodium. Am J Kidney Dis. 2006;48(1):151-154.
International Medical Case Reports Journal

\section{Publish your work in this journal}

The International Medical Case Reports Journal is an international, peer-reviewed open-access journal publishing original case reports from all medical specialties. Previously unpublished medical posters are also accepted relating to any area of clinical or preclinical science. Submissions should not normally exceed 2,000 words or

\section{Dovepress}

4 published pages including figures, diagrams and references. The manuscript management system is completely online and includes a very quick and fair peer-review system, which is all easy to use. Visit $\mathrm{http}: / /$ www.dovepress.com/testimonials.php to read real quotes from published authors. 